\title{
EDITORIAL
}

\section{Exercise-induced asthma: is there space for late-phase reactions?}

\author{
D.G. Peroni, A.L. Boner
}

Exercise challenge provokes bronchoconstriction in the majority of asthmatics. The reaction is particularly frequent in childhood, with an estimated prevalence of 70$90 \%$ in asthmatic children, because of the high level of physical activity in this age group [1, 2]. Bronchoconstriction is maximal 5-10 min after the challenge and tends to a complete recovery within $30-90 \mathrm{~min}$, depending on the degree of the initial response. Although the topic has been extensively published, there are still diverse opinions about the existence of an exercise-induced late asthmatic response.

\section{Mechanisms of exercise-induced asthma}

The mechanisms of exercise-induced asthma (EIA) are not completely clear, and there are controversies about the precise nature of the stimuli responsible for inducing bronchoconstriction [3]. This contributes to maintaining the debate on the occurrence of late-phase reactions (LPR). The determinants of the bronchoconstrictor response are most likely the temperature and the water content of the inspired air and the minute ventilation during exercise; the inflammation of the airways and the underlying degree of airway responsiveness play a further contributory role.

MCFADDEN and co-workers [4] have provided evidence that the respiratory heat loss during exercise, which causes airway cooling followed by rapid rewarming, may act as the appropriate stimulus for EIA. The rapid resupply of heat to the airways may cause asthma by means of an exaggerated hyperaemia and bronchial oedema [4]. There are many studies supporting the respiratory heat loss theory and the consequent thermal changes in the airways as the stimulus for EIA [3]. DEAL et al. [5] and MCFADDEN and co-workers [6] measured the temperature at different points of the tracheobronchial tree using thermocouples and clearly demonstrated that the fall in the airway temperature is directly related to the minute ventilation and inversely related to the inspired air temperature and water content. These variations are present both in normal and asthmatic subjects. Some subjects may develop EIA because of an increased sensitivity of their airways due to the previous degree of inflammation or to the difference in postexertional thermal events, since asthmatic airways rewarm twice as rapidly as those of controls [7]. However, at the present time, there is a lack

Correspondence: A.L. Boner, Clinica Pediatrica Università di Verona, Policlinico Borgo Roma, 37134 Verona, Italy and Istituto Pio XII, Misurina, Belluna, Italy. of evidence of direct changes in the airway blood flow due to airway temperature variations.

The second major hypothesis concerning the mechanisms of EIA was proposed by ANDERSON and co-workers [8]. They suggested that the respiratory water loss during exercise can lead to a hypertonicity of the airway lining fluid, and that the osmotic and not the cooling effect of exercise due to evaporated water is the more important factor in determining EIA. This theory is supported by other data [3]. Furthermore, in a recent study, ArgYros et al. [9] found that the EIA is correlated to the loss of mucosal water and that it can be achieved without significant heat loss or airway cooling. ANDERSON and co-workers [10] suggested that the hypertonicity of the airway lining fluid may induce mediator release by mast cells. This mechanism has been studied by direct measurements of mediator release induced by hypertonicity, hyperventilation and exercise challenge, or by evaluation of the effects of specific mediator antagonists. The contact with hypertonic solution (HS) is able to induce histamine release from mast cells that is dose-dependent and peaks between 1 and 5 min after the stimulus [11]. However, in vivo there are conflicting results, with some studies confirming blood histamine release during EIA [12-14], and others failing to demonstrate any increase $[15,16]$. Recently, the technique of isolated airway segment lavage (IASL) after challenge of an isolated airway segment with HS, has made it possible to demonstrate histamine release with hypertonicity in one study [17], and no effect in another [18]. The same conflicting results were obtained using the exercise or the isocapnic hyperventilation (ISH) challenge [19, 20].

Even if several studies have failed to demonstrate mediator variations in EIA, the use of mediator antagonists has added support for a role of mediators in the pathogenesis of EIA. The use of a selective histamine (H1)receptor antagonist, such as terfenadine, has been shown to protect against the bronchoconstrictor response to exercise [21, 22]. Furthermore, the role of leukotrienes in EIA has been studied: it has been shown that leukotriene $\mathrm{D}_{4}\left(\mathrm{LTD}_{4}\right)$ was increased in bronchoalveolar lavage (BAL) fluid after ISH challenge [19], but other authors have failed to confirm these data in EIA [20,23]. KIKAWA et al. [24] used an improved methodology for leukotriene measurement and showed increased urinary levels of leukotriene $\mathrm{E}_{4}\left(\mathrm{LTE}_{4}\right)$ following exercise test in asthmatic children with EIA. The difficulty in demonstrating increases in leukotriene concentrations in BAL fluid may be due to the lack of sensitivity of the available assays or to the small contribution of the leukotriene in this fluid compartment in comparison to the whole body 
content [3]. A clear indication of the role of these molecules in EIA can be drawn from studies evaluating the effects of $\mathrm{LTD}_{4}$ receptor antagonists in the prevention of EIA. There is evidence that EIA can be prevented by prechallenge treatment with potent, high affinity, $\mathrm{LTD}_{4}$ receptor antagonists [25-27].

VeNGE et al. [28] studied the possible role of eosinophils in EIA. They found increased levels of serum eosinophilic cationic protein (ECP) in subjects with EIA, with a correlation between pre-exercise ECP levels and the following fall in peak expiratory flow [28]. This study indicated that the ECP variations in EIA may be similar to those observed in allergen-induced asthma, and this may have many implications on the occurrence of late reactions. However, the elevated levels of ECP may reflect the ongoing airway inflammation and the consequent increase in bronchial hyperresponsiveness (BHR) to several nonspecific stimuli, including exercise.

\section{Late-phase reactions (LPR)}

An editorial on this topic appeared in the Journal in 1989 , indicating that the question has been much debated and is still unresolved [29]. Few papers have, in the meantime, added fresh knowledge on this topic, and the evidence for late-phase reactions in EIA has been drastically reduced.

The initial observation by BIERMAN et al. [30] in 1980 was extended by LEE et al. [31], who were able to demonstrate a LPR 3-6 h after exercise associated with an increase in serum neutrophil chemotactic activity. They found a correlation between the magnitude of the early and late reactions, but no other difference in clinical severity indices and degree of BHR between children developing LPR or not [31].

Several studies have described the occurrence of a LPR with a wide range of prevalence $(10-89 \%)$ [30-36]. However, as many other studies have failed to demonstrate the occurrence of a LAR, its existence has mainly been attributed to bias in the methods employed [37-42]. The major criticism has been the lack of a control day. The presence of control days was recommended for future studies on exercise-induced late reactions by LEE et al. [29] in the previous editorial. In the experimental design, the presence of control days, using nonspecific bronchial challenges or simply evaluating pulmonary function values at regular intervals, makes it possible to compare spontaneous variations in lung function to those observed during the exercise day. In other words, it should be determined whether decrements of airway function may be related not only to the challenge itself but also to the normal diurnal variations, or simply as the results of withdrawal of regular medications in asthmatic subjects exposed to the exercise challenge.

Our own group has published two studies in children showing that LPR after exercise was present in $46 \%$ of the first [33] and $16 \%$ of the second [43] study population. However, in a following study in which we specifically investigated, by comparison with control days, the reproducibility of exercise-induced LPR and it relationship to BHR, we were unable to demonstrate the occurrence of a LPR [42]. In a minority of patients, the early response after exercise was followed by a "late" deterioration in lung function, but this pattern was not reproducible.
These patients also presented a fall in lung function of similar degree during the control days. The late response did not develop 1 week later when the exercise challenge was repeated [42].

Recently, STENTON et al. [44] published a statistical method for the identification of LPR in individual subjects, using hourly measurements of lung function on control days. Whilst the original paper was designed to provide more sensitive identification and interpretation of reactions to allergens and occupational sensitizers [44], in the present issue of the Journal, HofsTra et al. [45] have applied an analogous method to consider day-today variability in pulmonary function on control days to the study of LPR in children with EIA. Utilizing a multiple linear regression analysis for each patient to evaluate the occurrence of LPR, they have randomly evaluated a cohort of children with EIA by comparing lung function tests on a control day without challenge, a challenge day with inhaled histamine and a challenge day with an exercise running. The histamine and exercise challenge days gave similar degree of bronchoconstriction immediately after challenge, but the authors did not observe any late asthmatic reaction associated with exercise. The results are not novel; however, the methodological approach to the material is unusual: the response to exercise challenge and the response to another nonspecific challenge were matched, and in addition to a control day without challenge, applied in a randomized order. Therefore, the statistical methods, previously applied in the field of occupational asthma [44], were extended to identify the LPR after exercise in asthmatic children.

It has now been clearly demonstrated that the LPR following antigen challenge is associated with a significant influx of inflammatory cells (eosinophils, neutrophils, etc.) that is present in the bronchial mucosa at 6 $\mathrm{h}$ [46]. The pathology of the antigen-induced LPR, characterized by the cellular influx and the mediator cascade, determines the late bronchoconstriction and the consequent increase of BHR. In EIA, there is no demonstration of cellular events in the mucosa and no increase in BHR. This suggests that exercise-induced and allergeninduced responses are pathophysiologically different. The nonreproducibility of the exercise-induced LPR confirms the absence of any link between the two reactions.

It has been suggested that the late-phase reaction after exercise might be a nonspecific phenomenon that derives from factors unrelated to the exercise challenge [38, 39], and may reflect within-day fluctuations in bronchial calibre in asthmatic patients. However, we believe that the existence of a late-phase reaction after exercise will be the subject of further controversy as we have not fully classified the mechanisms that determine exercise-induced asthma and have not completely excluded the possibility that exercise-induced asthma is accompanied by airway inflammation. More studies are needed in asthmatic patients to investigate the relationship between bronchial hyperresponsiveness, exercise-induced asthma and inflammatory changes in the airways.

\section{References}

1. Kattan M, Keens TG, Mellis CM, Levison H. The response to exercise in normal and asthmatic children. $J$ Pediatr 1978; 92: 718-721. 
2. Custovic A, Arifhodzic N, Robinson A, Woodcock A. Exercise testing revisited: the response to exercise in normal and atopic children. Chest 1994; 105: $1127-$ 1132.

3. Makker HK, Holgate ST. Mechanisms of exerciseinduced asthma. Eur J Clin Invest 1994; 24: 571-585.

4. McFadden ER. Respiratory heat and water exhange: physiological and clinical implications. J Appl Physiol: Respirat Environ Exercise Physiol 1983; 54: 331-336.

5. Deal EC, McFadden ER, Ingram RI, Jaeger JJ. Esophageal temperature during exercise in asthmatic and nonasthmatic subjects. J Appl Physiol: Respirat Environ Exercise Physiol 1979; 46: 484-490.

6. McFadden ER, Denison DM, Waller JR, Assoufi B, Peacock A, Sopwith T. Direct recordings of the temperature in tracheobronchial tree in normal man. J Clin Invest 1982; 69: 700-705.

7. Gilbert IA, Fouke JM, McFadden ER. Intra-airway thermodynamics during exercise and hyperventilation in asthmatics. J Appl Physiol 1988; 64: 2167-2174.

8. Anderson SD, Schoeffel RE, Follet R, Perry CP, Daviskas E. Sensitivity to heat and water loss at rest and during exercise in asthmatic patients. Eur J Respir Dis 1982; 63: 459-471.

9. Argyros GJ, Phillips YY, Rayburn DB, Rosenthal RR, Jaeger JJ. Water loss without heat flux in exercise-induced bronchospasm. Am Rev Respir Dis 1993; 147: 14191424.

10. Anderson SD. Is there a unifying hypothesis for exercise-induced asthma? J Allergy Clin Immunol 1984; 73 : 660-665.

11. Flint KC, Hudspith BN, Leung KB, Pearce FL, Brostoff $\mathrm{J}$. The hyperosmolar release of histamine from bronchoalveolar lavage mast cells and its inhibition by sodium cromoglycate. Thorax 1985; 40: 711.

12. Anderson SD, Bye PT, Schoeffel RE, Seale JP, Taylor KM. Arterial plasma histamine level at rest and during and after exercise in patients with asthma: effects of terbutaline aerosol. Thorax 1981; 36: 259-267.

13. Barnes PJ, Brown MJ. Plasma venous histamine in exercise and hyperventilation-induced asthma. Clin Sci 1981; 61: 661-665.

14. Lee TH, Nagakura T, Cromwell O, Brown MJ, Causon R, Kay AB. Neutrophil chemotactic activity (NCA) and histamine release in atopic and nonatopic individuals after exercise-induced asthma (abstract). Am Rev Respir Dis 1984; 129: 409-412.

15. Karr RM, Brach BB, Wilson MR, Anicetti V, Salvaggio JE. Changes in levels of arterial blood histamine during exercise-induced asthma (Abstract). J Allergy Clin Immunol 1979; 63: 154.

16. Harries MG, Burge PS, O'Brien I, Cromwell O, Pepys J. Blood histamine levels after exercise testing. J Allergy Clin Immunol 1979; 9: 437-441.

17. Gravelyn TR, Pan PM, Eschenbacher WL. Mediator release in an isolated airway segment in subjects with asthma. Am Rev Respir Dis 1988; 137: 641-646.

18. Makker HK, Walls AF, Goulding D, et al. Airway effects of local challenge with hypertonic saline in exerciseinduced asthma. Am J Respir Crit Care Med 1994; 149: 1012-1019.

19. Pliss LB, Ingerito EP, Ingram RH, Pichurko B. Assessment of bronchoalveolar cell and mediator response to isocapnic hyperpnea in asthma. Am Rev Respir Dis 1990; 142: 73-78.

20. Brodie DH, Eisman S, Ramsdell JW, Ferguson P, Schwartz LB, Wasserman SL. Airway levels of mast cell-derived mediators in exercise-induced asthma. Am Rev Respir Dis 1990; 141: 563-568.

21. Finnerty J, Holgate ST. Evidence of the role of histamine and prostaglandins as mediators in exercise-induced asthma: the inhibitory effect of terfenadine and flurbiprofen alone and in combination. Eur Respir J 1990; 3: 540-557.

22. Badier M, Beaumont D. Attenuation of hyperventilationinduced bronchospasm by terfenadine: a new antihistaminic. J Allergy Clin Immunol 1988; 81: 437-440.

23. Jarjour NN, Calhoun WJ, Stevens CA, Salisbury BS. Exercise-induced asthma is not associated with mast cell activation or airway inflammation. J Allergy Clin Immunol 1992; 89: 60-68.

24. Kikawa Y, Miyanomae T, Inoue Y. Urinary leukotriene $\mathrm{F}_{4}$ after exercise challenge in children with asthma. $J$ Allergy Clin Immunol 1992; 89: 1111-1119.

25. Finnerty JP, Wood-Baker R, Thomson H, Holgate ST. Role of leukotrienes in exercise-induced asthma: inhibitory effect of ICI 204,219, a potent leukotriene $\mathrm{D}_{4}$-receptor antagonist. Am Rev Respir Dis 1992; 145: 746-749.

26. Makker HK, Lau LC, Thomson HW, Binks SM, Holgate ST. The protective effect of inhaled $\mathrm{LTD}_{4}$-receptor antagonist, ICI 204,219, against exercise-induced asthma. Am Rev Respir Dis 1993; 147: 1413-1418.

27. Robushi M, Riva E, Fuccella LM. Prevention of exercise-induced bronchoconstriction by a new leukotriene antagonist (SK\&F 104353): a double-blind study versus disodium cromoglycate and placebo. Am Rev Respir Dis 1992; 145: 1285-1288.

28. Venge P, Henriksen J, Dahl R. Eosinophils in exerciseinduced asthma. J Allergy Clin Immunol 1991; 88: 699704.

29. Lee TH, O'Hickey SP. Exercise-induced asthma and late-phase reactions. Eur Respir J 1989; 2: 195-197.

30. Bierman CW, Spiro SG, Petheran I. Late response in exercise-induced asthma (abstract). J Allergy Clin Immunol 1980; 65: 206.

31. Lee TH, Nagakura T, Papageorgiou N, Iikura Y, Kay AB. Exercise-induced late asthmatic reactions with neutrophil chemotactic activity. N Engl J Med 1983; 308: 1502-1505.

32. Iikura Y, Inui H, Nagakura T, Lee TH. Factors predisposing to exercise-induced late asthmatic responses. $J$ Allergy Clin Immunol 1985; 75: 285-289.

33. Boner AL, Niero E, Antolini I, Warner JO. Biphasic (early and late) asthmatic responses to exercise in children with severe asthma, resident at high altitude. Eur J Pediatr 1985; 144: 164-166.

34. Boulet LP, Legris C, Turcotte H, Hebert J. Prevalence and characteristics of late asthmatic responses to exercise. J Allergy Clin Immunol 1987; 80: 655-662.

35. Speelberg B, Van der Berg NJ, Oosthoek CHA, Verhoeff NP, Van der Brink WT. Immediate and late asthmatic responses induced by exercise in patients with reversible airflow limitation. Eur Respir J 1989; 2: 402-408.

36. Verhoeff NP, Speelberg B, Van den Berg NJ, Oosthoek $\mathrm{CH}$, Stijnen ST. Real and pseudo late asthmatic reactions after submaximal exercise challenge in patients with bronchial asthma: a new definition for late asthmatic responses after exercise challenge. Chest 1990; 98: 1194-1199.

37. Dahl R, Henriksen JM. Development of late asthmatic reactions after allergen or exercise challenge tests. Eur J Respir Dis 1980; 61: 320-324.

38. Rubinstein I, Levison H, Slutsky AS, et al. Immediate and delayed bronchoconstriction after exercise in patients with asthma. N Engl J Med 1987; 317: 482-485. 
39. Zadawski DK, Lenner KA, McFadden ER. Re-examination of the late asthmatic response to exercise. Am Rev Respir Dis 1988; 137: 837-841.

40. Karjalainen J. Exercise response in 404 young men with asthma: no evidence for a late asthmatic reaction. Thorax 1991; 46: 100-104.

41. Crimi E, Balbo A, Milanese M, Miadonna A, Rossi GA, Brusasco V. Airway inflammation and occurrence of delayed bronchoconstriction in exercise-induced asthma. Am Rev Respir Dis 1992; 146: 507-512.

42. Boner AL, Vallone G, Chiesa M, Spezia E, Fambri L, Sette L. Reproducibility of late-phase pulmonary response to exercise and its relationship to bronchial hyperreactivity in children with chronic asthma. Pediatr Pulmonol 1992; 14: 156-159.
43. Boner AL, Sette L, Piacentini G, Peroni D, Warner JO. Exercise-induced biphasic responses and methacholine reactivity in asthma. Ann Allergy 1990; 65: 284-286.

44. Stenton SC, Avery AJ, Walters EH, Hendrick DJ. Statistical approaches to the identification of late asthmatic reactions. Eur Respir J 1994; 7: 806-812.

45. Hofstra WB, Sterk PJ, Neijens HJ, et al. Occurrence of a late response to exercise in asthmatic children: multiple regression approach using time-matched baseline and histamine control days. Eur Respir J 1996; 9: 1348-1355.

46. Montefort S, Gratziou C, Goulding D, et al. Bronchial biopsy evidence for leukocyte infiltration and upregulation of leukocyte-endothelial cell adhesion molecules 6 hours after local allergen challenge of sensitized asthmatic airways. J Clin Invest 1994; 93: 1411-1421. 